\title{
Evidence of the Impact of Methods of Implementation of IFRS on the Relevance of Accounting Information
}

\author{
Youssef Alami \\ Departement of Management \\ National School Of trade and Management of Tangier, Morocco \\ Mohamed Rachid Ouezzani \\ Departement of Management \\ National School Of trade and Management of Tangier,Morocco
}

Received: October 19, 2014 Accepted: November 3, 2014

doi:10.5296/ber.v5i1.6467 URL: http://dx.doi.org/10.5296/ber.v5i1.6467

\begin{abstract}
We have introduced a new classification of methods of implementation of IFRS based on the three criteria: The conformity with the IFRS Issued by the IASB, the necessity of a regulatory passage and the policy of implementation. On the basis of this classification, we have established an empirical study to examine the effect of these methods of implementation of IFRS on the relevance of the accounting Information. As a sample, we have taken several companies listed on the stock market of 8 countries adopting the IFRS with different methods of implementation. The results found show that the method of implementation of IFRS impacts significantly the relevance of the accounting information. Additionally, the comparison of the relevance of the accounting information demonstrates a better quality in countries adopting methods which are conform to IFRS compared to those opting for methods less conform. Thus, these results complement the diverse studies on the quality of the accounting information and open up new lines of researches.
\end{abstract}

Keywords: Impact, Methods, Implementation, IFRS, Relevance

\section{Introduction}

Following the implementation of IFRS by the European Union via the regulation CE 1606, several other countries have made the implementation or began to study the possible application of the IASB standards. Indeed, in October 2003 Australia by its financial Reporting Council has urged company boards and management to prepare early for the 
adoption of IFRS-based accounting standards in Australia. In 2002, The Accounting Practices Board in South Africa announced that it has a policy of harmonizing Statements in accordance with the IAS. The years following 2002 have known the adoption of IFRS by many countries.

In 2013, according to the survey conducted by the IFRS Foundation to centralize information available to allow measuring of progress of each jurisdiction, the results showed that of the 66 surveyed countries, $80 \%$ have already adopted IFRS mandatory for all or almost all companies making public offerings and most of those that remain have made significant progress in this direction.

This extension of the implementation of IFRS in many countries has been accompanied by a growing interest of researchers for the study of the qualitative characteristics of the accounting information. The relevance, one of these characteristics has been studied by the majority of these researches. The analysis of these studies shows different effects depending on the country studied, the sample used, the method used and the variables chosen. Thus, Morais and Curto (2009) have found that the relevance of the value of the accounting information of companies in 14 European countries has increased after the mandatory adoption of IFRS; Chalmers et al. (2011) have indicated that the benefits have become more relevant with a result opposed to the book value of equity following the adoption of IFRS by the Australian companies. Other studies, concerning other countries have found contrary results such as Eccher and Healy (2000) who have found that the IFRS were almost similar in terms of relevance that the Chinese standards; Hung and Subramanyam (2007) have enunciate that the informational relevance of equity under IFRS was less than the German standards. This difference in results between countries led us to wonder about the potential effect of the method of implementation chosen on the relevance of the accounting information. Indeed, although the studies on the relevance of the accounting information are numerous, the method of implementation has not been an object of a study to show its impact on the relevance.

Thus, according to the study of Zeff and Nobes (2010), the policy of implementation of IFRS around the world can be categorized into four principal methods with different degrees of compliance to the IFRS issued by the IASB. This multitude of methods chosen by the countries for the implementation of IFRS raises some important questions. Can we classify the methods of implementation of IFRS? Is that these methods of implementation of IFRS impact the relevance of the accounting information?

To answer these questions, we analyze in the first section the methods of implementation of IFRS enunciated by Zeff and Nobes (2010) and we propose a new classification of methods of implementation of IFRS based on the criteria used by these authors, as well as on other ones. On the basis on this classification, we have selected a sample of 1765 companies from eight countries which have implemented the IFRS with different methods of implementation that we present in the second section as well as the models of analysis used. In third section, we analyze the significant results found showing a significant effect of methods of implementation of IFRS on the relevance of the accounting information. Finally, we draw the 
summary and the conclusions of this study.

\section{Background of Study}

In this section, we debate the methods of implementation of IFRS presented by Zeef and Nobes (2010) and establish our repartition of methods of implementation of IFRS based on other criteria in addition to those used by these authors. Next, we present a literature review of studies concerning the relevance of the accounting information.

\subsection{Methods of Implementation of IFRS}

Although the IFRS have been adopted by many countries in the world, the implementation of these standards differs from one country to another. Zeef and Nobes have conducted a ranking of methods of implementation of IFRS for listed companies and have given examples of countries adopting them. Thus, according these authors, the first method called "adopting the process" has been chosen in South Africa and Israel; this method is the most advanced method and the most compliant with the IFRS issued by the IASB; it gives to the international accounting setter a legal notoriety and consists in the application of standards published by this organization without a passage through a regulatory adoption process.

The second method named "standard by standard" in its two first levels "adoption as issued by the IASB" adopted in Canada and "Fully Converged with IFRS" in Australia are compliant with the IFRS Issued by the IASB; these methods require a passage trough a regulatory process; the first sub-method "adoption as issued by the IASB" is similar to the method "adopting the process" but needs an automatic regulatory passage; the second sub-method "Fully Converged with IFRS" consists in the convergence of all national accounting standards to IFRS. The third sub-method of the "standard by standard" method named "Adoption as issued by the IASB with deletions" is applied in the European Union; thus, only the local standards adopted by the E.U. are applied by the concerned companies.

The third implementation method called "optional" is chosen in Switzerland; it is considered by Zeef and Nobes as possibly conform to the IFRS and aims to give the opportunity to companies to choose between two or more of accounting standards.

The fourth method called "not fully converged" is applied in China; it is considered as compliant "Unlikely" with the IFRS as issued by the IASB and consists in the convergence of the most part of national accounting standards to IFRS.

The examination of this classification made by Zeef an Nobes shows that it does not distinguish between the method of implementation and the policy of implementation of IFRS. In fact, according to these authors, the methods of implementation of IFRS called «optional» is considered by the authors as a method of implementation and have given the Switzerland as an example of countries adopting this method. For us, it is important to distinguish between the method of implementation and the policy of implementation. Thus this country requires for all listed firms to use U.S. GAAP or IFRS for the preparation of financial statements (Christopher S. Armstrong, 2008) (Deloitte, 2008). If a company chooses the IFRS, the Version of these standards required is the IASB version. Thus, for this country the 
implementation method chosen is the "adoption as issued by the IASB" and the policy is to implement the IFRS optionally.

Based on the criterion of the compliance to IFRS chosen by Zeef and Nobes (2010) to classify the implementation methods, we have added other ones to classify the methods of implementation of IFRS:

- The first criterion is the use of a passage by a regulatory process;

- The second one is the policy of implementation.

Thus, the Figure 1 below shows the various methods and policies of implementation of IFRS.

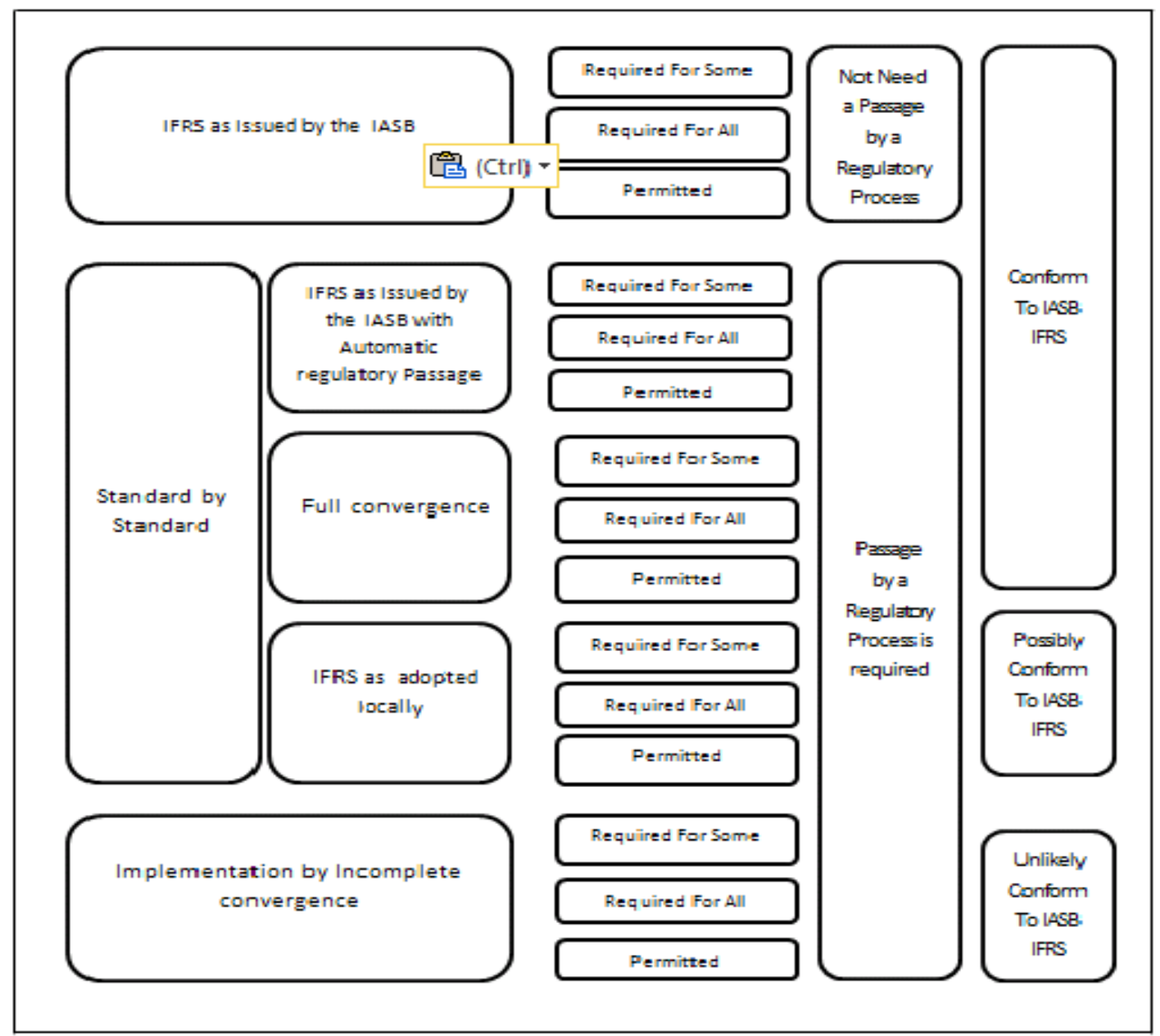

Figure 1. Classification of Methods and Policies of implementation of IFRS

The Figure 1 gives a classification of methods and policies of implementation of IFRS. A country that has chosen to implement the IFRS can opt for three principal methods: The "adoption of IFRS as Issued by the IASB" which is the most method conforms to the IFRS; this method doesn't require for the application of IFRS any passage across a regulatory process; all the standards published by the international accounting standard setter must be applied by the concerned entities. The Second method is the "Standard By standard" implementation; it can be divided into three Sub-Methods which are the "application of IFRS 
as Issued by the IASB with an automatic regulatory passage", the "full convergence" and the "application of IFRS as adopted locally". These three sub-methods need a passage by a regulatory process. This passage can be automatic without any change or deletion. In this case, we are talking about the adoption of "IFRS as issued by the IASB with an automatic regulatory passage". Also, this passage by the regulatory process can take several times and can delete some norms; in this case we talk about the adoption of "IFRS as adopted locally". The last sub-method of the "standard by standard" is the full convergence; through this method, the regulator chooses to completely change its accounting standards according to the IFRS. The sub-method method "incomplete convergence" is a process of change of local standards in compliance with the IFRS but with keeping intact some accounting standards.

\subsection{Literature Review on the Relevance of Accounting Information}

Accounting is a quantitative technique of collecting and interpreting information to define an image of an entity. Indeed, whatever the conceptual framework or standards applied, it appears that the objective of accounting is to provide useful information for assessing an entity. Indeed, the Accounting information should serve to inform their users about the value of companies. It is therefore essential to assess whether accounting is able to achieve this goal and to provide informative accounting content to reflect a relevant valuation of the company to a specific date. The different accounting standards can also be assessed through their ability to meet this evaluation objective. The Relevance of accounting information is judged through the quality of the relationship between accounting information and the value of the company. According to Landsman and Maydew (1999), information has informative content if it is marginal compared to other sources of alternative and competitive information and it confirms or full prior information. Based on this definition, two concepts are to consider namely the intrinsic character and the redundancy of information as demonstrated by the study of Dumontier (1999). According to this Author, the intrinsic character considers that given information content must complement anterior information. The redundant characteristic corresponds to the fact that the information confirms the anterior redundant information. Historically speaking; two currents of literature are distinguished. The first current corresponding to the approach of relevance by the bias of redundant information content. This current of study considers that the role of accounting information is to evaluate firms. The Relevant accounting information gives an evaluation of the company. The second, evaluates the relevance of accounting information through its intrinsic characteristic. This current appreciates the impact of accounting announcements on the price movement of the securities or trading volume. It considers whether the market reacts to accounting information. The figure 2 below illustrates these two approaches of study of the relevance. 


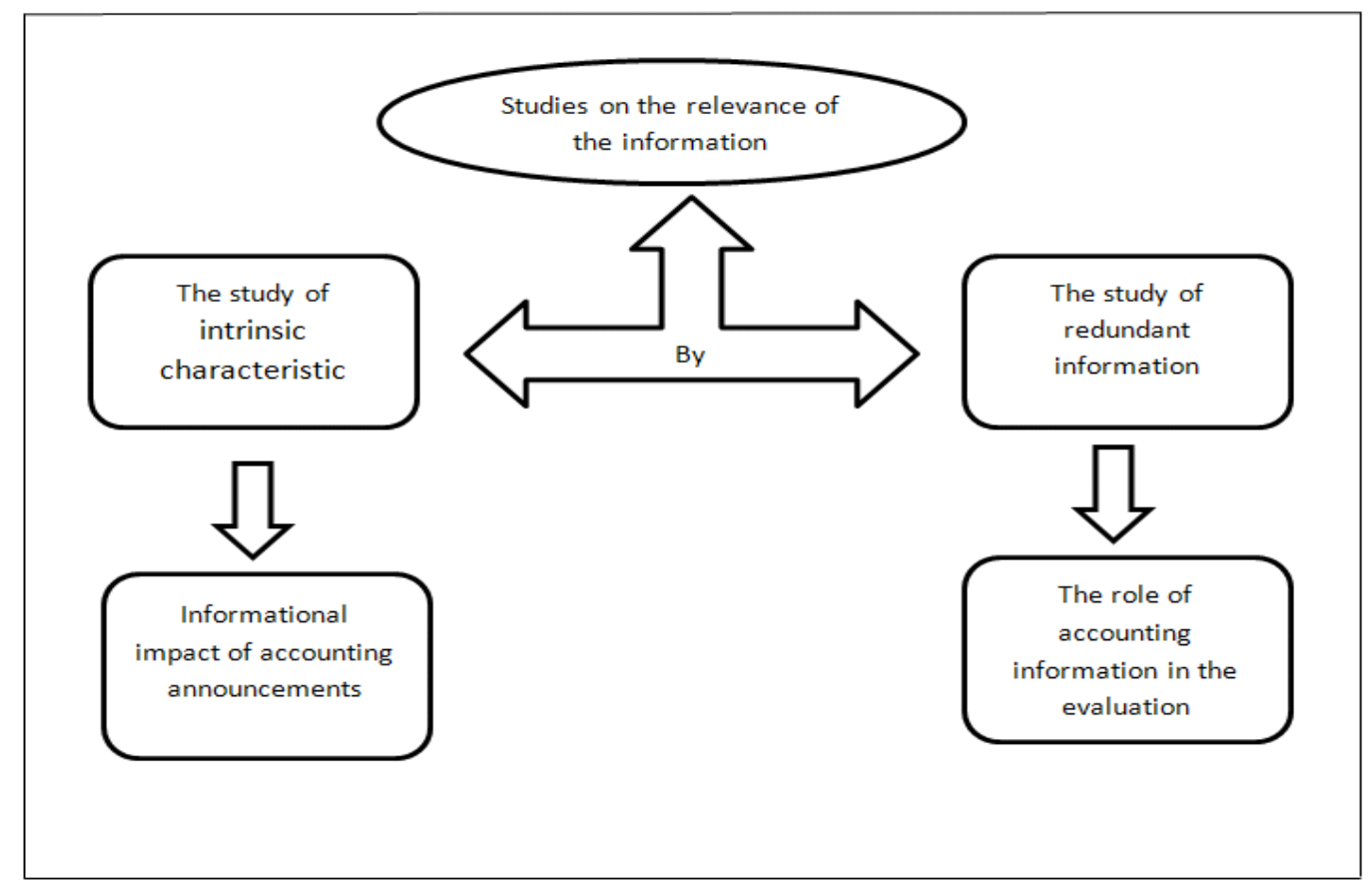

Figure 2. Studies on the relevance of the information

\section{Research Hypothesis}

Taking as base the classification of methods of implementation that we have presented above and the results of the most part of studies on the relevance demonstrating that the effect of the implementation of IFRS on the relevance of accounting information is positive -Morais and Curto (2009) have noticed through a sample of companies listed in 14 European countries that the relevance of the value of the financial statements of these countries had increased following their transition to IFRS, Chalmers et al. (2008) have concluded that the IFRS communicate more additional information for the investors in relation with the goodwill that the Australian standards and have founded (2011) that the benefits have become more relevant following the implementation of IFRS-; the examination of results of these studies demonstrate that the effect of IFRS on the relevance of the accounting information is variable from a country to another; thus, this difference in results leads to the first hypothesis:

H1: The Compliance of methods of implementation of IFRS chosen by a country influences the relevance of the accounting information.

The difference of results founded by several studies demonstrate a better relevance of the accounting information established in IFRS compared to the local accounting standards of several countries as demonstrated by the study of Auer (1996) enunciating that the information in IAS were moderately higher in informational content than the Swiss standards; Bartov, Goldberg and Kim (2005) showing the high significant superiority of IFRS compared to the German local repository and Eccher and Healy (2000) showing that the accounting information in IFRS was slightly more relevant than Chinese standards; this prompts the second research hypothesis: 
$\mathrm{H} 2$ : The relevance of the accounting information of countries opting for compliant methods of implementation of IFRS is better than the relevance of the accounting information of countries opting for methods which are less compliant.

\section{Methodology}

In the present subsections, we present the data; the model used and explains how we compute our empirical measure of the relevance.

\subsection{Sample Selected and Statistics}

The sample we have chosen is composed of companies listed on the stock markets of 8 countries that have made before the last 5 years an implementation of IFRS with different methods of implementation. The objective is to study the effect of the implementation method of IFRS on the relevance of accounting information. For the stock prices and the accounting data, they are from the database S\&P Capital IQ.

The observation period is 4 years from 2010 to 2013. This period was chosen because the accounting information after the implementation of IFRS for a country of our sample is 4 years (Canada, the only country adopting the implementation method "IFRS as Issued by the IASB with an automatic regulatory passage").However, we have conducted a number of adjustments and eliminations in order to ensure representativeness of the sample and avoid bias that can affect the results of our research. Thus, we eliminate companies whose observations are not complete in terms of information on the equity, earnings, stock prices and the standards adopted.

Table 1.Sample selected by Country

\begin{tabular}{|c|c|c|c|}
\hline Country/Jurisdiction & Israel & South Africa & Canada \\
\hline $\begin{array}{c}\text { Implementation } \\
\text { Method }\end{array}$ & $\begin{array}{c}\text { IFRS As Issued By the } \\
\text { IASB }\end{array}$ & IFRS As Issued By the IASB & $\begin{array}{l}\text { IFRS As Issued By the } \\
\text { IASB with Automatic } \\
\text { Regulatory Passage }\end{array}$ \\
\hline $\begin{array}{l}\text { Rules for listed } \\
\text { filings }\end{array}$ & $\begin{array}{l}\text { Required for consolidated } \\
\text { financial statements } \\
\text { except for banking } \\
\text { institutions }\end{array}$ & $\begin{array}{l}\text { Required for consolidated } \\
\text { and standalone/separate } \\
\text { financial statements }\end{array}$ & $\begin{array}{l}\text { Required for interim and } \\
\text { annual financial } \\
\text { statements relating to } \\
\text { annual periods }\end{array}$ \\
\hline Selected Companies & 88 & 126 & 399 \\
\hline Initial observations & 1145 & 1621 & 4846 \\
\hline $\begin{array}{c}\text { Observations } \\
\text { Retained }\end{array}$ & 1056 & 1512 & 4788 \\
\hline IFRS Compliance & Yes & Yes & Yes \\
\hline Country/Jurisdiction & Hong Kong & Belgium & Denmark \\
\hline $\begin{array}{c}\text { Implementation } \\
\text { Method }\end{array}$ & Full Convergence & IFRS as adopted Locally & IFRS as adopted Locally \\
\hline
\end{tabular}


2015, Vol. 5, No. 1

\begin{tabular}{|c|c|c|c|}
\hline $\begin{array}{l}\text { Rules for listed } \\
\text { filings }\end{array}$ & $\begin{array}{l}\text { HKFRS Required Annual } \\
\text { accounts of a listed } \\
\text { company }\end{array}$ & $\begin{array}{l}\text { Required for consolidated } \\
\text { financial statements of } \\
\text { companies listed, banks and } \\
\text { other credit institutions }\end{array}$ & $\begin{array}{l}\text { Required for consolidated } \\
\text { and standalone/separate } \\
\text { financial statements }\end{array}$ \\
\hline Selected Companies & 191 & 56 & 142 \\
\hline Initial observations & 2347 & 694 & 1754 \\
\hline $\begin{array}{c}\text { Observations } \\
\text { Retained }\end{array}$ & 2292 & 672 & 1704 \\
\hline IFRS Compliance & Yes & Yes & Yes \\
\hline Country/Jurisdiction & Germany & China & Total \\
\hline $\begin{array}{c}\text { Implementation } \\
\text { Method }\end{array}$ & IFRS as adopted Locally & Incomplete Convergence & 5 Methods \\
\hline $\begin{array}{l}\text { Rules for listed } \\
\text { filings }\end{array}$ & $\begin{array}{l}\text { Required for consolidated } \\
\text { and standalone/separate } \\
\text { financial statements }\end{array}$ & $\begin{array}{l}\text { Required for consolidated } \\
\text { financial statements and for } \\
\text { some companies in the } \\
\text { financial industry and }\end{array}$ & $\begin{array}{c}\text { Required for at last } \\
\text { consolidated financial } \\
\text { statements }\end{array}$ \\
\hline Selected Companies & 112 & 651 & 1765 \\
\hline Initial observations & 1421 & 8245 & 22073 \\
\hline $\begin{array}{c}\text { Observations } \\
\text { Retained }\end{array}$ & 1344 & 7812 & 21180 \\
\hline IFRS Compliance & Yes & Yes & Yes/No \\
\hline
\end{tabular}

Table 2. Descriptive Statistics

\begin{tabular}{|c|c|c|c|c|c|c|}
\hline & $\mathrm{N}$ & Minimum & Maximum & Average & Standard Deviation & Variance \\
\hline Market Value2010 & 1765 & 0,00 & 404,94 & 8,81 & 25,74 & 662,42 \\
\hline Market Value2011 & 1765 & 0,00 & 416,00 & 7,57 & 23,51 & 552,54 \\
\hline Market Value2012 & 1765 & 0,00 & 555,00 & 8,57 & 28,60 & 818,14 \\
\hline Market Value2013 & 1765 & 0,00 & 404,94 & 8,48 & 24,76 & 613,03 \\
\hline EPS 10 & 1765 & 0,00 & 96,10 & 0,91 & 4,50 & 20,27 \\
\hline EPS 11 & 1765 & 0,00 & 70,20 & 0,81 & 3,60 & 12,98 \\
\hline EPS 12 & 1765 & 0,00 & 276,10 & 0,93 & 7,64 & 58,44 \\
\hline EPS 13 & 1765 & 0,00 & 43,00 & 0,69 & 2,40 & 5,78 \\
\hline BVS 10 & 1765 & 0,00 & 493,50 & 6,79 & 26,12 & 682,35 \\
\hline BVS 11 & 1765 & 0,00 & 485,30 & 7,08 & 26,79 & 717,55 \\
\hline BVS 12 & 1765 & 0,00 & 633,70 & 7,37 & 30,03 & 901,93 \\
\hline BVS 13 & 1765 & 0,00 & 485,30 & 6,61 & 23,52 & 552,99 \\
\hline Growth 10 & 1765 & 1,70 & 10,40 & 6,16 & 3,52 & 12,42 \\
\hline Growth 11 & 1765 & 0,40 & 9,30 & 5,24 & 3,27 & 10,72 \\
\hline Growth 12 & 1765 & $-2,40$ & 7,70 & 3,58 & 3,37 & 11,35 \\
\hline Growth 13 & 1765 & $-1,90$ & 7,70 & 3,81 & 3,20 & 10,22 \\
\hline
\end{tabular}




\subsection{Empirical Models}

The models that we use to study the effects of methods chosen for the implementation of IFRS in a country on the relevance of the accounting information are based on the theoretical works of Ohlson $(1995 ; 1999)$ and Feltham and Ohlson (1995). These authors managed to revive the approach of abnormal profits (residual income) initiated by Preinreich (1938). In the aforementioned approach, they start from a logic based on the distribution of wealth for measuring wealth creation from abnormal discounted profits. According to Lee (1999), measuring the value of a company through abnormal profits comes from the empirical works in financial economics of Preinreich (1938) - developed later in the research of Edwards and Bell (1961) Peasnell (1982). In general, this model expresses the value of a company by the amount of capital invested and the wealth created. It also reflects on accounting; in fact the model becomes equal to the sum of the book value of equity and abnormal discounted earnings.

The First model that we used is intended to give an estimation of price of the action of a company by the earnings per share, the equity per share, the growth in the country and the method of implementation that the country has chose. This model is used to measure the effects of methods of implementation of IFRS on the relevance of accounting information. The second model is indented to compare the relevance of the accounting information between the methods of implementation of IFRS.

Model (1): Pit= B0 + B1 EPSit + B2 BVSit + B3Growthit +B (B4 -B7) Methodsit +eit

Model (2): Pit= B0 + B1 EPSit + B2BVSit + eit

With:

Pit : The Market Value of the firm $i$ at the end of year $t$

EPSit : The Ratio of earnings per share of firm $\mathrm{i}$ in year $\mathrm{t}$

BVSit : The Ratio of equity per share of firm $\mathrm{i}$ in year $\mathrm{t}$

Growthit : Growth in the country to which the firm belongs of firm $\mathrm{i}$ in year $\mathrm{t}$

Methodsit : The method of implementation in the country to which the firm belongs of firm $\mathrm{i}$ in year t. It is a categorical variable with 5 categories: B4 = IFRS as issued by the IASB; B5= IFRS as issued by the IASB with automatic regulatory passage; B6= Full convergence; B7= IFRS as adopted locally; Reference Variable= Incomplete convergence. Indeed, because categorical predictor variables cannot be entered directly into a regression model, dichotomous variables could be constructed that would contain the same information as the categorical variables. In general, a categorical variable with $\mathrm{k}$ levels will be transformed into k-1 variables each with two levels. Thus, the 5 methods of implementation of IFRS are converted into 4 dichotomous variables by the dummy coding. The dependent variable is the implementation method "Incomplete convergence". In terms of coding system, we use the deviation coding. This system compares the mean of the dependent variable for a given level to the overall mean of the dependent variable. In our case, the first comparison is about the 
implementation method "IFRS as Issued by IASB" to all other methods of implementation. The second comparison is about the implementation method "IFRS as Issued by IASB with automatic regulatory passage" to all other methods of implementation. The third comparison compares the implementation method "Complete Convergence" to all other methods of implementation and the fourth comparison compares the implementation method "IFRS as adopted locally" to all other methods of implementation. This regression coding scheme yields the comparisons described above:

\begin{tabular}{|c|c|c|c|c|c|}
\hline & & \multicolumn{4}{|c|}{ Dummy Coded Variables } \\
\hline Meth. & $\begin{array}{c}\text { IFRS as } \\
\text { Issued by } \\
\text { IASB }\end{array}$ & $\begin{array}{c}\text { IFRS as Issued by IASB } \\
\text { with automatic } \\
\text { regulatory passage }\end{array}$ & $\begin{array}{c}\text { Complete } \\
\text { Convergence }\end{array}$ & $\begin{array}{c}\text { IFRS As } \\
\text { Adopted } \\
\text { Locally }\end{array}$ \\
\hline IFRS as Issued by IASB & 1 & 1 & 0 & 0 & 0 \\
\hline $\begin{array}{c}\text { IFRS as Issued by IASB } \\
\text { with automatic regulatory }\end{array}$ & 2 & 0 & 1 & 0 & 0 \\
\hline passage & 3 & 0 & 0 & 1 & 0 \\
\hline IFRS as Adopted Locally & 4 & 0 & -1 & 0 & -1 \\
\hline Incomplete Convergence & 5 & -1 & 0 & & 0 \\
\hline
\end{tabular}

eit: Other informational pertinence of firm in year $\mathrm{t}$

\section{Results of the empirical Study}

The empirical analysis that we conducted through the two models presented above aims to study the effect of the method of implementation on the relevance of accounting information (Model 1) and to compare the relevance between the methods of implementation of IFRS (Model 2). The results are presented in two points:

\subsection{The Effect of Methods of Implementation on the Relevance}

The results of model 1 show that the variables "IFRS as issued by the IASB", "IFRS with Automatic Regulatory Passage", "full convergence", "IFRS as adopted Locally" and are significant. In fact, the t-statistics of these variables are high in absolute terms (between 2,92 and 6,729) and the P-values are very low $(<0,004)$. Based on the results of the table 3 below, we can say that the relevance of accounting information differs according to the method of implementation of IFRS chosen by a country. For the three remaining variables namely "EPS", "BVS" and "Growth", the results show that these variables are very significant. Indeed, the t-stat of these variables are very high (between 2,691 and 45,967) and the P values are very low $(<0,0090)$. Thus, these variables provide relevant information. In terms of relevance, the analysis of the coefficient R2 of the entire sample comprising 1765 companies distributed in 8 countries adopting diverse implementation methods of IFRS shows a high relevance of the accounting information for all the countries implementing IFRS. Indeed, the coefficient of determination R2 is ranging between $70.10 \%$ and $72.90 \%$ for the last four years 2010-2013. Also, the F test shows that the set of explanatory variables that are in the model 1 
provide useful information for the estimation of the Market value of companies.

Table 4. Results of the regression for the Model 1

\begin{tabular}{|c|c|c|c|c|c|}
\hline \multicolumn{6}{|c|}{$\mathrm{M}(1): \mathrm{P}_{\mathrm{i}=} \mathrm{B}_{0}+\mathrm{B}_{1} \mathrm{EPS}_{\mathrm{it}}+\mathrm{B}_{2} \mathrm{BVS}_{\mathrm{it}}+\mathrm{B}_{3}$ Growth $_{\mathrm{it}}+\mathrm{B}\left(\mathrm{B}_{4}-\mathrm{B}_{8}\right)$ Method $_{\mathrm{it}}+\mathrm{e}_{\mathrm{it}}$} \\
\hline & & 2010 & 2011 & 2012 & 2013 \\
\hline \multirow[t]{3}{*}{ Constant } & $\mathrm{B}_{0}$ & $-35,1220$ & $-60,4740$ & $-64,0090$ & $-70,5380$ \\
\hline & $\mathrm{t}$ & $-2,5040$ & $-3,9590$ & $-4,8040$ & $-5,9620$ \\
\hline & Sign. & 0,0120 & 0,0000 & 0,0000 & 0,0000 \\
\hline \multirow[t]{3}{*}{ EPS } & B1 & 0,7460 & 1,2260 & 0,1420 & 3,6980 \\
\hline & $\mathrm{t}$ & 8,4490 & 11,5350 & 2,6910 & 20,1540 \\
\hline & Sign. & 0,0000 & 0,0000 & 0,0070 & 0,0000 \\
\hline \multirow[t]{3}{*}{ BVS } & $\mathrm{B}_{2}$ & 0,7190 & 0,5870 & 0,7410 & 0,5280 \\
\hline & $\mathrm{t}$ & 45,9670 & 40,0100 & 51,4320 & 28,7880 \\
\hline & Sign. & 0,0000 & 0,0000 & 0,0000 & 0,0000 \\
\hline \multirow[t]{3}{*}{ Growth } & $\mathrm{B}_{3}$ & 1,1640 & 3,0990 & 3,1890 & 3,3290 \\
\hline & $\mathrm{t}$ & 3,6480 & 3,4570 & 4,1550 & 5,0020 \\
\hline & Sign. & 0,0090 & 0,0010 & 0,0000 & 0,0000 \\
\hline \multirow[t]{3}{*}{ IFRS as Issued IAS } & $\mathrm{B}_{4}$ & $-6,1010$ & $-11,0410$ & $-15,3680$ & $-14,9460$ \\
\hline & $\mathrm{t}$ & $-2,9200$ & $-4,0760$ & $-4,6600$ & $-6,1310$ \\
\hline & Sign. & 0,0040 & 0,0000 & 0,0000 & 0,0000 \\
\hline \multirow[t]{3}{*}{ IFRS as Issued With Aut. Reg. Pass } & $\mathrm{B}_{5}$ & $-4,9910$ & $-5,2770$ & $-10,4950$ & $-12,3630$ \\
\hline & $\mathrm{t}$ & $-3,2020$ & $-3,5570$ & $-4,3630$ & $-5,9420$ \\
\hline & Sign. & 0,0010 & 0,0000 & 0,0000 & 0,0000 \\
\hline \multirow[t]{3}{*}{ Fully Conv. } & $\mathrm{B}_{6}$ & $-12,8720$ & $-15,9660$ & $-14,2070$ & $-18,3410$ \\
\hline & $\mathrm{t}$ & $-3,4130$ & $-4,7070$ & $-5,8270$ & $-6,7290$ \\
\hline & Sign. & 0,0010 & 0,0000 & 0,0000 & 0,0000 \\
\hline \multirow[t]{3}{*}{ IFRS as adopted Locally } & $\mathrm{B}_{7}$ & $-4,2410$ & $-5,0240$ & $-8,4950$ & $-8,6780$ \\
\hline & $\mathrm{t}$ & $-3,1020$ & $-3,1470$ & $-3,9540$ & $-4,0145$ \\
\hline & Sign. & 0,0010 & 0,0000 & 0,0000 & 0,0000 \\
\hline \multirow[t]{3}{*}{ Compliance IFRS } & $\mathrm{B}_{8}$ & 40,5850 & 61,7770 & 73,7800 & 79,7460 \\
\hline & $\mathrm{t}$ & 3,1250 & 4,3150 & 5,1540 & 6,3360 \\
\hline & Sign. & 0,0020 & 0,0000 & 0,0000 & 0,0000 \\
\hline \multicolumn{2}{|l|}{$\mathrm{R} 2$} & 0,7250 & 0,7010 & 0,7030 & 0,7290 \\
\hline \multicolumn{2}{|l|}{$\mathrm{F}}$. & 663,1300 & 587,2680 & 594,7200 & \\
\hline \multicolumn{2}{|l|}{ Sign } & 0,0000 & 0,0000 & 0,0000 & 0,0000 \\
\hline \multicolumn{2}{|l|}{ Durbin Watson } & 1,3310 & 1,5490 & 1,6580 & 1,9390 \\
\hline
\end{tabular}

\subsection{Comparison of the relevance between the methods of implementation of IFRS}

The results of regressions performed via the model 2 show a good relevance of the accounting information for the three main methods of implementation of IFRS "IFRS as Issued by the IASB", "Standard by Standard" and "Incomplete convergence". Indeed, for the three methods of implementation of IFRS between 2010 and 2014, the regression coefficient 
ranged between $73 \%$ and $82 \%$.

Also, the comparison of results between the three methods of implementation shows a better relevance of the accounting information for the methods of implementation "IFRS as Issued by the IASB" selected by two countries of our sample Israel and South Africa and the "Standard by Standard "with its tree sub-methods "IFRS as issued by the IAS with an automatic regulatory passage", "Full convergence" and "IFRS as adopted locally" chosen by Canada, Hong Kong, Belgium, Denmark and Germany compared to the relevance of accounting information obtained by the method of implementation "Incomplete Convergence" selected in China.

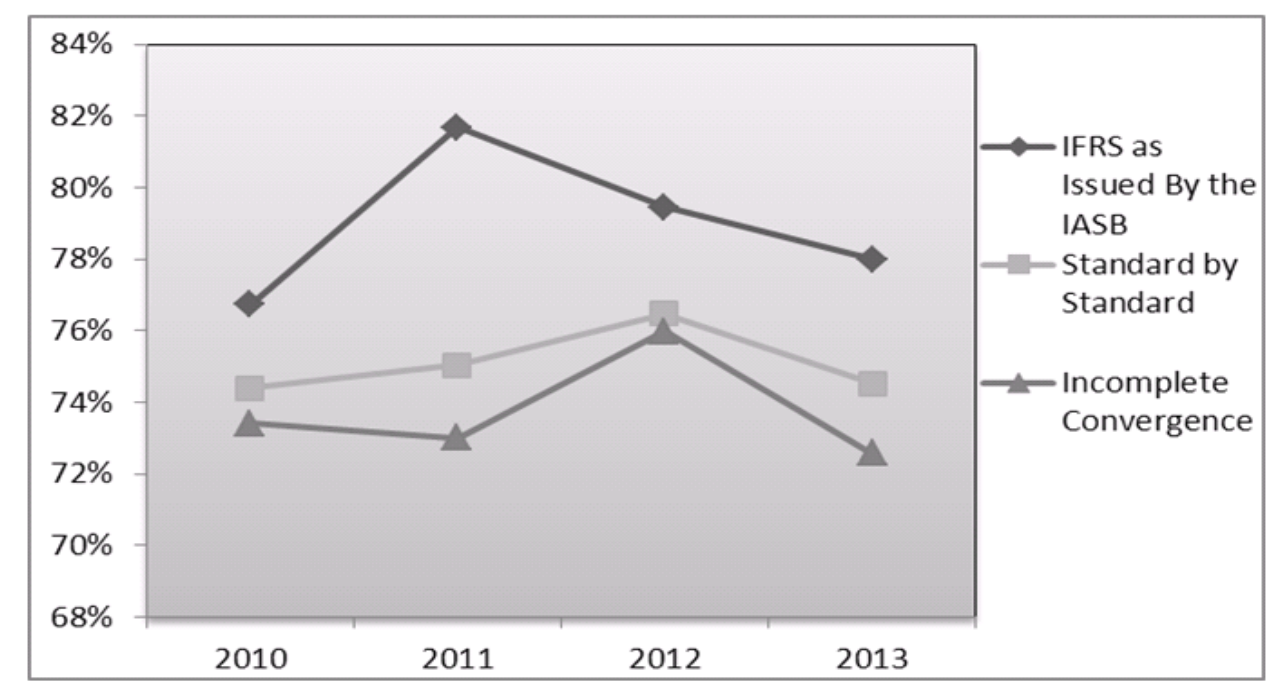

Figure 3. Comparison of R2 between the Methods of Implementation of IFRS

Table 5. Results of the regression for the Model 2

\begin{tabular}{|c|c|c|c|c|c|c|}
\hline \multirow{2}{*}{$\begin{array}{l}\text { Implementation } \\
\text { Method }\end{array}$} & \multicolumn{6}{|c|}{$M(2): P_{i t=} B_{0}+B_{1} E S_{i t}+B_{2} B_{V S}+e_{i t}$} \\
\hline & \multicolumn{2}{|c|}{ Variable } & 2010 & 2011 & 2012 & 2013 \\
\hline \multirow{13}{*}{ IFRS as Issued By the IASB } & \multirow{4}{*}{ EPS } & R2 & 0,8641 & 0,8140 & 0,7456 & 0,7620 \\
\hline & & B1 & 6,5718 & 6,5586 & 9,3321 & 9,6692 \\
\hline & & $\mathrm{t}$ & 8,5294 & 11,0490 & 11,3528 & 11,9602 \\
\hline & & Sign. & 0,0000 & 0,0000 & 0,0000 & 0,0000 \\
\hline & \multirow{4}{*}{ BVS } & $\mathrm{R} 2$ & 0,6005 & 0,7711 & 0,7438 & 0,6309 \\
\hline & & B2 & 0,4394 & 0,2352 & 0,1252 & 0,4544 \\
\hline & & $\mathrm{t}$ & 3,4512 & 2,6895 & 1,2470 & 4,1232 \\
\hline & & Sign. & 0,0000 & 0,0000 & 0,2138 & 0,0000 \\
\hline & \multicolumn{2}{|c|}{$\mathrm{R} 2$} & 0,7673 & 0,8168 & 0,7946 & 0,7800 \\
\hline & \multicolumn{2}{|c|}{ F. } & 347,8071 & 470,2694 & 408,2066 & 187,5850 \\
\hline & \multicolumn{2}{|c|}{ Sign } & 0,0000 & 0,0000 & 0,0000 & 0,0000 \\
\hline & \multicolumn{2}{|c|}{ Durbin Watson } & 1,8745 & 1,6745 & 1,6487 & 1,7451 \\
\hline & & R2 & 0,3036 & 0,3373 & 0,1153 & 0,5556 \\
\hline
\end{tabular}




\begin{tabular}{|c|c|c|c|c|c|c|}
\hline \multirow{11}{*}{ Standard By Standard } & \multirow{3}{*}{ EPS } & B1 & 0,6835 & 1,2793 & 0,1770 & 4,2104 \\
\hline & & $\mathrm{t}$ & 5,5159 & 8,1598 & 2,3975 & 16,7937 \\
\hline & & Sign. & 0,0000 & 0,0000 & 0,0167 & 0,0000 \\
\hline & \multirow{4}{*}{ BVS } & $\mathrm{R} 2$ & 0,7052 & 0,6523 & 0,6838 & 0,6207 \\
\hline & & B2 & 0,7767 & 0,6314 & 0,7881 & 0,5658 \\
\hline & & $\mathrm{t}$ & 37,3034 & 31,6592 & 42,6715 & 22,1062 \\
\hline & & Sign. & 0,0000 & 0,0000 & 0,0000 & 0,0000 \\
\hline & \multicolumn{2}{|c|}{$\mathrm{R} 2$} & 0,7439 & 0,7504 & 0,7647 & 0,7452 \\
\hline & \multicolumn{2}{|c|}{ F. } & 1302,6897 & 1100,1804 & 1123,6241 & 1311,9665 \\
\hline & \multicolumn{2}{|c|}{ Sign } & 0,0000 & 0,0000 & 0,0000 & 0,0000 \\
\hline & \multicolumn{2}{|c|}{ Durbin Watson } & 1,6475 & 1,7834 & 1,6782 & 1,7954 \\
\hline \multirow{12}{*}{ Incomplete Convergence } & \multirow{4}{*}{ EPS } & $\mathrm{R} 2$ & 0,3737 & 0,4291 & 0,5101 & 0,4448 \\
\hline & & B1 & 10,3180 & 7,8300 & 8,1840 & 10,5439 \\
\hline & & $\mathrm{t}$ & 10,1224 & 11,9004 & 13,5754 & 13,0756 \\
\hline & & Sign. & 0,0000 & 0,0000 & 0,0000 & 0,0000 \\
\hline & \multirow{4}{*}{ BVS } & $\mathrm{R} 2$ & 0,2425 & 0,2478 & 0,2872 & 0,2540 \\
\hline & & B2 & 2,0032 & 1,1724 & 1,1694 & 1,3271 \\
\hline & & $\mathrm{t}$ & 14,9516 & 12,8483 & 15,1615 & 12,2800 \\
\hline & & Sign. & 0,0000 & 0,0000 & 0,0000 & 0,0000 \\
\hline & \multicolumn{2}{|c|}{$\mathrm{R} 2$} & 0,7341 & 0,7301 & 0,7598 & 0,7259 \\
\hline & \multicolumn{2}{|c|}{ F. } & 894,7179 & 876,4775 & 1024,8124 & 857,8663 \\
\hline & \multicolumn{2}{|c|}{ Sign } & 0,0000 & 0,0000 & 0,0000 & 0,0000 \\
\hline & \multicolumn{2}{|c|}{ Durbin Watson } & 1,7458 & 1,7541 & 1,7412 & 1,4785 \\
\hline
\end{tabular}

\section{Summary and Discussion}

The opening of economies, the internationalization of companies and of the information systems have been the source of many changes not only in the economic and financial areas of countries but also in the techniques and means used by the companies in these countries such as accounting. Indeed, the accounting can not be considered as a mean to schematize, identify and record numerical data to define an agent or an entity but must be considered as a mean that can be used by the different parts of the entity. To achieve this, the accounting information must possess a number of qualitative characteristics like comparability, reliability and relevance.

Thus, in order to improve these qualitative characteristics of the accounting and financial information, the countries proceed through their national normalizer to the amelioration of the accounting adopted standards. These changes can take many forms and can include a broad category or a small category of companies. During the last two decades, the International Accounting scene has undergone several changes. A significant number of countries have made changes to their accounting regulation. The majority of these countries have relied on the experience and the independence of the international standard setter IASB. These countries, therefore, chose to implement the standards issued by this institution for at 
least a category of firms. However, the implementations method differs from one jurisdiction to another. Several countries opted for a direct adoption of the IFRS issued by the IASB, while others preferred to keep a control and passing the standards of the international accounting standard setter by a local adoption process. Consequently, the choices in terms of methods of implementation of IFRS differed from one country to another. This difference raises the question of the conformity of these methods to the IFRS and the impact of the method chosen on the quality of the accounting information.

This paper presents a new classification based, in addition to the criterion adopted by Zeef and Nobes (2010), on the criterion of the policy of implementation. Thus, we have retained five methods and sub-methods namely "IFRS as issued by the IASB", "IFRS as issued by the IASB with an automatic Regulatory passage", "full convergence", "IFRS as adopted locally" and the "Incomplete convergence ".

The empirical study -that we have conducted over a period of 4 years from 2010 to 2013 on the basis of a sample of 1765 companies in 8 countries who have implemented the IFRS for at last a category of firms with different methods of implementation- have revealed the significant impact of methods of implementation on the relevance of the accounting information.

Also, the comparison of results has demonstrated a better relevance of the accounting information in countries opting for the implementation of IFRS for methods fairly close and conform to IFRS issued by the IASB than those who have selected methods of implementation of IFRS less conform.

As limit to this research, we emphasize the period of the study which is from 2010 to 2013. This period of four years has been limited by the number of years in which the IFRS information is available for a country of our sample which is Canada. In fact this country is the only one around the world adopting the Sub-method "Implementation with an automatic Regulatory passage". It has implemented the IFRS in 2011 with the obligation for the companies concerned to prepare an opening IFRS balance sheet for the year 2010 .

\section{References}

Auer, K., (1996). Capital market reactions to earnings announcements: empirical evidence on the difference in the information content of IAS-based earnings and EC-Directives-based earnings, The European Accounting Review, 5-4, 587- 623.

Chalmers K., Clinch G., Godfrey J. M., Wei Z. (2012). Intangible assets, IFRS and analysts' earnings forecasts, Accounting and finance : journal of the Accounting Association of $\begin{array}{llll}\text { Australia } \quad \text { New } & \text { Zealand } & \text { 52-3, } & \end{array}$ http://dx.doi.org/10.1111/j.1835-2561.2008.0028.x

Christopher, S., \& Armstrong M. E. (2008). Market Reaction to the Adoption of IFRS in Europe. Harvard Business School

Deloitte, (2008). Switzerland. Retrieved from IAS Plus: http://www.iasplus.com/country/switzerl.htm 
Dumontier, P. (1999). Information comptable et création de valeur: lecours de bourse ne suffit pas, Revue française de gestion: 99-105.

Deloitte, (2014). Use of IFRS by jurisdiction, http://www.iasplus.com/en/resources/ifrs-topics/use-of-ifrs.

Eccher, E., \& P. Healy. (2000). The Role of International Accounting Standards in Transitional Economies: A study of the People's Republic of China, Working Paper Series, Massachusetts Institute of Technology.

Edwards, E., \& Bell, P. (1961). The Theory and Measurement of Business Income.Berkeley: University of California Press.

Feltham, G. A., \& Ohlson J. A. (1995).Valuation and Clean Surplus Accounting for Operating and Financial Activities. Contemporary Accounting Research 11, 689-731.

Bartov, E., Goldberg, S., \& Kim, M., (2005). Comparative value relevance among German, U.S., and international accounting standards: A German stock market perspective, Journal of Accounting, Auditing and Finance: 20-2, 95-119.

Landsman W., \& E. Maydew, (1999). Has the Information Content of Annual Earnings Announcements Declined in the Past Three Decades ? ,Working paper, University of North Carolina

Hung, M., and K.R. Subramanyam. (2007). Financial Statement Effects of the Adoption of International Accounting Standards: The Case of Germany, Review of Accounting Studies 12-4, 623-657. . http://dx.doi.org/10.1007/s11142-007-9049-9

IFRS Fondation, (2014). Jurisdiction Profiles, last updated 14 April 2014, http://www.ifrs.org/Use-around-the-world/Pages/Jurisdiction-profiles.aspx.

Lee, Charles. (1999). Accounting-Based Valuation: Impact on Business Practices and Research, Accounting Horizons 13, 413-426.

Morais A. I., \& Curto J. D. (2009). Mandatory Adoption of IASB Standards: Value Relevance and Country-Specific Factors, Australian Accounting Review, 19, 128-143.

Pricewaterhouse Coopers, (2013). IFRS adoption by country, last update April 2013, http://www.pwc.com/us/en/issues/ifrs-reporting/publications/ifrs-status-country.jhtml

Peasnell, Kenneth. (1982). Some Formal Connections between Economic Values and Yields and Accounting Numbers. Journal of Business, Finance and Accounting 9, 361-381.

Preinreich, G. (1938). Annual Survey of Economic Theory: The Theory of Depreciation, Econometrica, 6, 219-241.

Ohlson, J. A. (1995). Earnings, Book Values, and Dividends in Equity Valuation, Contemporary Accounting Research 661-687. http://dx.doi.org/10.1111/j.1911-3846.1995.tb00461.x

Ohlson, J. A. (1999). Earnings, Book Values, and Dividends in Equity Valuation: An 
Empirical Perspective, Contemporary Accounting Research.

Zeff, S. A., \& C. W. Nobes. (2010). Commentary: Has Australia (or Any Other Jurisdiction) 'Adopted' IFRS?, Australian Accounting Review 20-2, 178-184. http://dx.doi.org/10.1111/j.1835-2561.2010.00089.x

\section{Copyright Disclaimer}

Copyright for this article is retained by the author(s), with first publication rights granted to the journal.

This is an open-access article distributed under the terms and conditions of the Creative Commons Attribution license (http://creativecommons.org/licenses/by/3.0/). 